ORIGINAL ARTICLE

\title{
Assessing the implementation of food defense requirements in industrial meat- based food processors
}

\section{Avaliação da implementação de requisitos de defesa alimentar em indústrias produtoras de alimentos à base de carne}

\author{
Elisabete Filipa Praia ${ }^{1}$, Ana Rita Henriques ${ }^{1 *}$ (D) \\ ${ }^{1}$ Universidade de Lisboa, Faculdade de Medicina Veterinária, Departamento de Produção Animal e Segurança \\ Alimentar, Lisboa, Portugal.
}

${ }^{*}$ Corresponding Author: Ana Rita Henriques, Universidade de Lisboa, Faculdade de Medicina Veterinária, Departamento de Produção Animal e Segurança Alimentar, Av. da Universidade Técnica, 1300-477, Lisboa Portugal, e-mail: anaritah@fmv.ulisboa.pt

Cite as: Praia, E. F., \& Henriques, A. R. (2021). Assessing the implementation of food defense requirements in industrial meat-based food processors. Brazilian Journal of Food Technology, 24, e2020201.

https://doi.org/10.1590/1981-6723.20120

\begin{abstract}
Food defense is the effort to protect food from causing harm to the consumer, including security procedures to mitigate intentional acts of adulteration. To assure entry in new markets, food companies need to develop and implement food defense strategies through third-party certification. Although there are some programs designed to assist food business operators in creating effective food defense strategies, this is still not regarded as a priority by food companies. As a first aim of this work, a first-party audit of two meat-producing industries was performed to verify the implementation of food defense requirements. The second purpose of the work was to compare vulnerabilities identified in those two food industries with the ones detected in other previously certified food units in Portugal. For such, a food defense requirements checklist was prepared for the audit and a private certification database was consulted to compare audit results with those from other food business operators certified by at least one international food defense standard. Audit results revealed that both industries were above $50 \%$ in overall compliance regarding food defense requirements; still the main vulnerabilities were related to the lack of a food defense plan, the failure to identify critical areas, ineffective warning systems and no training in food defense. Similar vulnerabilities were detected in other certified national food business operators, leading to the conclusion that implementation of food defense requirements seems to be underestimated. As an intervention strategy proposal, food defense training would be of upmost importance to get staff and managers acquainted with the concept.
\end{abstract}

Keywords: Food defense; Food industry; Vulnerability; Intentional adulteration; Audit; Checklist.

\section{Resumo}

A defesa alimentar é o esforço para proteger os alimentos de causar danos ao consumidor, incluindo procedimentos para mitigar atos intencionais de adulteração. Para assegurar a entrada em novos mercados, os gestores da indústria de alimentos podem desenvolver e adotar estratégias de defesa alimentar, visando à certificação por referenciais internacionais. Embora existam alguns programas concebidos para ajudar as indústrias alimentares a criar e 
implementar estratégias eficazes de defesa alimentar, isto ainda não é visto como uma prioridade para as indústrias de alimentos. O primeiro objetivo deste trabalho foi auditar duas indústrias de produtos à base de carne para verificar a implementação de requisitos de defesa alimentar. O segundo objetivo foi comparar as vulnerabilidades detectadas nas duas indústrias auditadas com as de outras indústrias alimentares certificadas. Para isso, foi preparada uma lista de verificação de auditoria aos requisitos de defesa alimentar. A base de dados de um organismo de certificação foi consultada para comparar os resultados de auditoria com aqueles de outras indústrias alimentares certificadas por pelo menos um dos referenciais internacionais que contempla requisitos de defesa alimentar. Os resultados das auditorias revelaram que as principais vulnerabilidades estavam relacionadas à inexistência de um plano de defesa alimentar, a falhas na identificação de áreas críticas, a sistemas de alerta ineficazes e à falta de formação em defesa alimentar. Essas vulnerabilidades foram igualmente detectadas noutras indústrias alimentares certificadas, levando a concluir que a implementação de requisitos de defesa alimentar parece subestimada. Como proposta de intervenção, a formação em defesa alimentar será fundamental para facilitar a compreensão do conceito de defesa alimentar pelo pessoal e por gestores da indústria de alimentos.

Palavras-chave: Defesa alimentar; Indústria alimentar; Vulnerabilidade; Atos mal-intencionados; Auditoria; Lista de verificação.

\section{Introduction}

The global food trade is complex and ever-evolving. Due to discrepancies in food law systems of different countries, harmonization of international food safety rules is of upmost importance to reduce trade barriers. In the last few years, regulatory authorities, food business operators and consumers started focusing on the need for effective food defense systems (Davidson et al., 2017). The Global Food Safety Initiative (GFSI) set up voluntary food safety management requirements based on internationally-recognized standards (Global Food Safety Initiative Foundation, 2020). Under these standards, food business operators are required to develop and implement food defense strategies to assure market entry through third-party certification of their management systems (Manning, 2019). Certification standards include those benchmarked to GFSI, such as British Retail Consortium (BRC), International Featured Standards (IFS) and Food Safety System Certification (FSSC) 22000 (Global Food Safety Initiative Foundation, 2020; Manning, 2019). These standards include food defense requirements, such as the implementation of a hazard analysis and related risk assessment.

At present, food business operators are increasingly required to comply with food quality and safety management systems in order to expand their business at national and international level (Bogadi et al., 2016). The main initiators of food defense implementation in the food supply chain are retail networks, who condition their producers' certifications in accordance with one of the food safety systems' standards.

Food defense is the effort to protect food from causing harm to the consumer, encompassing active steps, protection activities and/or security assurance procedures that deliver product safety with regard to intentional acts of adulteration (Manning \& Soon, 2016). Intentional adulteration may take several forms, such as acts of terrorism, tampering by discontented employees, consumers, or competitors, as well as economically driven adulteration (Bogadi et al., 2016).

There are countless ways of causing intentional harm, both to the consumer and to an industrial unit, and, although uncommon, these actions can have serious consequences. Intentional adulteration incidents have been recorded at every major point along the farm-to-fork continuum: pre-harvest, processing, transportation, retail and at the consumer level (Fredrickson, 2014). From 1950 to 2008, a total of 729 confirmed incidents were reported in literature. Still, there is limited research, and publications on food defense at the food business operators' level are scarce (Manning, 2019). Nevertheless, food business operators can find guidance in online available materials and tools such as CARVER + Shock vulnerability assessment 
software, Food Defense Plan Builder and PAS 96:2017 “Guide to Protect and Defend Food and Drink from Deliberate Attack" (British Standards Institution, 2017; Food and Drug Administration, 2018, 2020).

As a first aim of this work, the authors audited two meat-producing industries in order to verify the implementation of food defense requirements; for such, a food defense requirements checklist was prepared. The second aim of the work was to compare identified vulnerabilities in those two food industries with the ones detected in other previously certified food units in Portugal.

\section{Materials and methods}

\subsection{Food defense audit of the industrial units}

To assess food defense requirements in industrial meat units, a checklist was designed based on the requirements of IFS, BRC and FSSC 22000 (British Retail Consortium, 2015; Foundation Food Safety System Certification 22000, 2019; International Featured Standards, 2014). The checklist considered 110 closed-ended questions with a yes or no answer, pooled into four groups: 1 - External security; 2 - Internal security, 3 - Personnel security and 4 - General requirements (Appendix A). The checklist was pre-tested in an industrial unit and necessary adjustments were done, namely suppressing duplicated questions and reformulating others, to enhance data collection. Each audit included i) an initial meeting with the industrial unit's manager and/or quality department head; ii) an onsite facilities assessment, including staff interviews, whenever necessary, to complete collected information; iii) an examination of documents and records relevant to compliance assessment. iv) a closing meeting, to resume main findings and assess probable causes and conclusions. Whenever possible, relevant information regarding food defense requirements was recorded.

The selection criteria for the audited food industries included: being a meat-based food producing industry officially approved for food processing and regularly inspected by food authorities and having a food safety management certification system according to standards that included food defense requirements.

\subsection{Comparison of food defense vulnerabilities in the audited industries with those of other certified companies}

To compare the food defense audit results of the two companies with those of other industries certified according to standards that consider food defense requirements (BRC, IFS and FSSC 22000), a consultation to a national private database was carried out. This database belongs to a private organization which operates globally and is concerned with certification of management systems, services, products and individuals, providing audit, inspection and training services.

Since there were very few meat sector industries certified according to at least one of the three standards (BRC, IFS and FSSC 22000), the study's authors decided to include all food industries certified by these standards. In this consultation, only industries certified between January 2014 and September 2016 were considered.

The MS Excel 2016 software (CMicrosoft Corporation, Redmond, United States of America) was used for data analysis.

\section{Results and discussion}

\subsection{Characterization of audited industries}

Two industrial units producing processed meat-based foods using pork as raw material and diverse technological processes were assessed (Table 1). 
Table 1. Characterization of audited meat-based food producing industries.

\begin{tabular}{cccccc}
\hline Industry & Location & Company size & $\begin{array}{c}\text { Number of } \\
\text { workers }\end{array}$ & $\begin{array}{c}\text { Type of meat- } \\
\text { based food } \\
\text { products }\end{array}$ & $\begin{array}{c}\text { Technological } \\
\text { process }\end{array}$ \\
\hline A & Industrial park & Small & 12 & Pork & $\begin{array}{c}\text { fermenting, drying } \\
\text { and smoking }\end{array}$ \\
\hline B & Industrial park & Medium & 300 & Pork & $\begin{array}{c}\text { cooking and } \\
\text { smoking }\end{array}$ \\
\hline
\end{tabular}

Industry A was a small-sized company, while industry B was a medium-sized enterprise, and they represent the largest proportion of Portuguese food-producing companies (PORDATA, 2020). These industries, located in industrial parks, had over ten years of existence and supplied the main food retail groups in Portugal. Both units were officially approved for food production activities and were regularly inspected by official controlling authorities. The two industries also had mature food safety management systems certified according to standards that included food defense requirements (such as ISO / TS 22002-1:2009) (International Organization for Standardization, 2009).

Industry A, located in the district of Portalegre, employed 12 workers and was classified as a small company (European Union, 2003). This industrial unit manufactured traditional Alentejo-style pork delicatessen, including chouriço, paio, salsichão and painho (Table 1). It featured a processing line for raw meat preparation, meat smoking rooms, a packaging room and a shipping and dispatch area.

Industry B, located in the district of Setúbal, employed 300 workers at the time of the audit, and was classified as a medium-sized company (European Union, 2003). This industrial unit processed meat-based foods, such as bacon, ham and sausages (Table 1). It included an abattoir and a meat delicatessen processing unit, operating in independent premises.

\subsection{Auditing food defense requirements}

Both industries were found to be above $50 \%$ in terms of overall compliance in the food defense audit (Table 2), with industry A presenting the lowest audit score (54\%) when compared to industry B (65\%).

Table 2. Industries overall and sector scores in the food defense requirements audit.

\begin{tabular}{cccccc}
\hline & \multicolumn{5}{c}{ Audit scores in percentage (proportion of compliance) } \\
\cline { 2 - 6 } Industry & $\begin{array}{c}\text { Overall } \\
(\text { max.110) }\end{array}$ & $\begin{array}{c}\text { External } \\
\text { security } \\
(\text { max.27) }\end{array}$ & $\begin{array}{c}\text { Internal } \\
\text { security } \\
(\text { max.32) }\end{array}$ & $\begin{array}{c}\text { Personnel } \\
\text { security } \\
(\text { max.16) }\end{array}$ & $\begin{array}{c}\text { General } \\
\text { requirements } \\
(\text { max. 35) }\end{array}$ \\
\hline $\mathrm{A}$ & $54 \%(59 / 110)$ & $19 \%(5 / 27)$ & $31 \%(10 / 32)$ & $19 \%(3 / 16)$ & $60 \%(21 / 35)$ \\
\hline $\mathrm{B}$ & $65 \%(71 / 110)$ & $59 \%(16 / 27)$ & $34 \%(11 / 32)$ & $25 \%(4 / 16)$ & $77 \%(27 / 35)$ \\
\hline
\end{tabular}

Industry A revealed consistently lower audit scores in all checklist groups (Table 2). It is important to mention that while both industrial units displayed several identical food defense vulnerabilities, none had developed a food defense plan, which is an essential part of vulnerability assessment and identification of mitigation measures. Small- and medium-sized companies often lack a food safety team or a resident food safety technician, which compromises ongoing training and timely development of food safety management systems (Henriques et al., 2017; Wallace et al., 2014).

At the end of each audit, detected vulnerabilities were reported to the manager and/or quality department and further discussed in order to understand potential causes for the non-conformity to requirements. 


\subsubsection{External security assessment}

In this group of requirements, industry A presented the lowest compliance (19\%), while industry B revealed a section score over $50 \%$ (Table 3 ).

Table 3. Audit scores in the "External security" group of requirements in both industries.

\begin{tabular}{cccccc}
\hline \multirow{2}{*}{ Industry } & \multicolumn{5}{c}{ Audit scores (proportion of compliance) } \\
\cline { 2 - 6 } & $\begin{array}{c}\text { External security } \\
\text { group } \\
(\text { max. 27) }\end{array}$ & $\begin{array}{c}\text { External } \\
\text { perimeter } \\
(\text { max. 3) }\end{array}$ & $\begin{array}{c}\text { Building and } \\
\text { structure } \\
(\text { max. 6) }\end{array}$ & $\begin{array}{c}\text { Access control } \\
\text { (max. 10) }\end{array}$ & $\begin{array}{c}\text { Shipping and } \\
\text { dispatching } \\
(\text { max. 8) }\end{array}$ \\
\hline $\mathrm{A}$ & $5 / 27(19 \%)$ & $0 / 3$ & $2 / 6$ & $1 / 10$ & $2 / 8$ \\
\hline $\mathrm{B}$ & $16 / 27(59 \%)$ & $2 / 3$ & $4 / 6$ & $5 / 10$ & $5 / 8$ \\
\hline
\end{tabular}

Both industries presented "External perimeter" vulnerabilities, such as damaged perimeter fences which did not allow for a complete separation from the outer environment. Industry A had a very low fence which did not provide adequate protection from the outside; no regular checking of the industrial perimeter was carried out, and there was no adequate lighting during periods of lower natural light. In industry B, a part of the fence was discontinued, allowing intruders to trespass from the outside; in this unit, at least two daily checks of the entire plant perimeter were done and sufficient lighting was in place during periods of less natural light. The external perimeter of a food unit is the first barrier of protection in preventing strangers' access to the plant (Holah, 2013).

Regarding "Building and structure" requirements, both industries were constructed using strong materials able to resist unlawful entry of intruders, and the buildings were adequately proofed. Still, other vulnerabilities were identified in industry A, such as lack of adequate protection of doors and windows that could be opened from the outside, as no locking mechanism or alarm existed. Regarding "Access control" requirements, in industry A there was no employee in charge of controlling access to the plant, and the main entrance door (for employees and visitors) lacked a locking mechanism, being supervised only by office staff that did not record entries and exits; also, in industry A, visitors were not identified, escorted or supervised while in the facility, which compromises access to critical areas. Industry B included a security post with a barrier at the unit's entrance and a gatekeeper controlling vehicle and people entries and exits, as well as recording those activities. However, in this industry, identification of visitors and temporary workers upon entrance was not carried out. In both units, no communication of employee dismissals was made to other staff members, including the gatekeeper in industry B, which did not ensure complete control of access by current and former employees. Dissatisfied employees have been linked to intentional adulteration events and potential threats (Bogadi et al., 2016).

Regarding "Shipping and dispatching" requisites, no regular recorded procedure existed for unexpected deliveries of raw materials/packaging/subsidiary materials. In this case, industry A presented more vulnerabilities, such as no monitoring of delivery activities, leaving it to the delivery driver. As such, unit A required no supplier's notification of raw materials delivery and no records of the driver's identification or the length of stay for delivery purposes. In Industry B, although an employee was assigned to monitor delivery activities, no records were kept of such supervision. Contrary to that, a study assessing implementation of a food defense plan in a Brazilian army organization reported rigorous monitoring and effective operations at the raw materials delivery stage, with these activities being supervised by trained personnel (Farias de Abreu et al., 2020). 


\subsubsection{Internal security assessment}

Considering "Internal security" requirements, industry A presented a compliance level of 31\% against $34 \%$ for industry B (Table 4).

Table 4. Audit scores of the "Internal security" group of requirements in both industries.

\begin{tabular}{ccccccc}
\hline \multirow{2}{*}{ Industry } & \multicolumn{5}{c}{ Audit scores (proportion of compliance) } \\
\cline { 2 - 7 } & $\begin{array}{c}\text { Internal } \\
\text { security } \\
\text { group } \\
\text { (max. 32) }\end{array}$ & $\begin{array}{c}\text { Raw materials } \\
\text { storage } \\
\text { (max. 6) }\end{array}$ & $\begin{array}{c}\text { Subsidiary } \\
\text { materials/ } \\
\text { chemical } \\
\text { storage } \\
\text { (max. 6) }\end{array}$ & $\begin{array}{c}\text { Final product } \\
\text { storage } \\
\text { (max. 6) }\end{array}$ & $\begin{array}{c}\text { Returned/ } \\
\text { withdrawn/ } \\
\text { suspicious } \\
\text { products } \\
\text { (max. 5) }\end{array}$ & $\begin{array}{c}\text { Access } \\
\text { control } \\
\text { (max. 9) }\end{array}$ \\
\hline $\mathrm{A}$ & $10 / 32(31 \%)$ & $2 / 6$ & $2 / 6$ & $2 / 6$ & $2 / 5$ & $2 / 9$ \\
\hline $\mathrm{B}$ & $11 / 32(34 \%)$ & $2 / 6$ & $2 / 6$ & $2 / 6$ & $2 / 5$ & $3 / 9$ \\
\hline
\end{tabular}

Regarding requirements aimed at assessing storage of raw and subsidiary materials, chemicals and final products, vulnerabilities were found in both industries. Both units had no access restriction to storage areas, which presented easily opened doors without a locking mechanism. Access to raw materials and final product storage areas should be restricted to those working in those areas and other authorized persons (Blanchfield, 2013). Considering storage of chemical products, industry B evidenced access control, as the warehouse was locked and located outside the main building, and kept written records of chemicals used, including product name, dosage, time and place or equipment in which it was used, besides the name of the employee who performed this task. Controlling use of chemicals is important, as several cases of food adulteration by chemicals have been reported (Davidson et al., 2017; Manning, 2019).

Although both industries have shown to have a specific place to store returned/withdrawn and suspicious products, personnel access to those places was not restricted and there were no records of the destination given to those products.

Considering access control, none of the industries had a list of employees/visitors (such as contractors or service providers) authorized to access critical areas, and these areas were not identified. In addition, an inventory of hazardous materials, such as knives and other sharp and blunt objects, was not carried out in both units, and there was free access by staff and/or visitors to the ventilation and air conditioning systems, water storage and power switchboard facilities. A study of food defense requirements in Japanese food factories and related facilities described a low level of access to critical areas (Kanagawa et al., 2014).

\subsubsection{Personnel security assessment}

"Personnel security" presented the lowest level of compliance in both units for all audited groups of requirements (Table 2 and 5).

Table 5. Audit scores of the "Personnel security" group of requirements in both industries.

\begin{tabular}{cccccc}
\hline Industry & \multicolumn{4}{c}{ Audit scores (proportion of compliance) } \\
\cline { 2 - 5 } & $\begin{array}{c}\text { Personnel } \\
\text { security group } \\
\text { (max. 16) }\end{array}$ & $\begin{array}{c}\text { Employee's } \\
\text { hiring (max. 3) }\end{array}$ & $\begin{array}{c}\text { Training } \\
\text { (max. 5) }\end{array}$ & $\begin{array}{c}\text { Personnel } \\
\text { behavior (max. 6) }\end{array}$ & $\begin{array}{c}\text { Employment } \\
\text { contract revision } \\
\text { (max. 2) }\end{array}$ \\
\hline $\mathrm{A}$ & $3 / 16(19 \%)$ & $1 / 3$ & $0 / 5$ & $2 / 6$ & $0 / 2$ \\
\hline $\mathrm{B}$ & $4 / 16(25 \%)$ & $1 / 3$ & $0 / 5$ & $3 / 6$ & $0 / 2$ \\
\hline
\end{tabular}


None of the industrial units had an established procedure for employee hiring, and none communicated to employees, when hiring, or to visitors, prior to entry, the location of critical areas within the industrial unit. Additionally, there was no evidence of background checking, including criminal records, of existing employees or potential candidates. Assessment of the criminal record of employees is very rare in Portuguese private companies, occurring mainly in the banking sector, or when hiring new employees for public services (Brasil, 2014). Background checks aim at gathering information on the criminal past of workers, in an attempt to select employees who have not been associated with malicious acts. Still, in industry B, a leaflet indicating the main rules to comply within the company was handed to all visitors before accessing their facilities and to new employees on the onboarding day. This induction training is critical in prompting correct attitudes by new employees (Sprenger, 2017). In industry B, employees had appropriate and differentiated clothing depending on their functional role, and these garments were washed in the unit's internal laundry. In industry A, despite each employee having clothing appropriate for their role, garments were not differentiated, and employees washed their own uniforms at home. In the food industry, washing of uniforms by the employees themselves is usually considered a hygienic flaw, as this procedure is not standardized and transport of the garments back to the food facilities is not controlled, leaving it to the discretion of each worker to adequately protect their belongings (Holah \& Taylor, 2003). However, not only do uniforms constitute a vehicle of contamination for food processing, but food defense consider the possibility of intentional exchange of uniforms between collaborators, which would facilitate access of employees to sections not assigned to them (Holah \& Taylor, 2003; United States Department of Agriculture Food Safety and Inspection Service, 2008). Another audit finding was that temporary workers were not properly identified as such in both industries, and there was no periodical routine inspection of employees' lockers. This lockers' checking routine encourages their regular cleaning and can have a deterrent effect for malicious acts (Farias de Abreu et al., 2020).

Considering food defense training in both industries, none of the employees interviewed mastered the concept, and there was no known procedure on how to react in the event of intentional food adulteration. No encouragement was given to employees to report suspicious activity and security violations. Engagement and awareness of all employees is very important to prevent malicious acts (British Standards Institution, 2017; British Retail Consortium, 2015). Training plays an important role in raising awareness about threats and malicious acts and should be regularly planned and implemented (Kanagawa et al., 2014). In both audited industries, it would be pertinent to conduct an initial food defense training, to get all the staff and manager/administration representatives acquainted with this concept.

Considering employment contract revision requirements, employees' dismissal was not communicated to other staff members, including security personnel. According to Blanchfield (2013), food industries should take appropriate precautions in the case of employee's dismissal, due to possible risks to food product's safety arising through disaffection or lack of continuing interest and commitment on the part of the employees concerned.

\subsubsection{General requirements assessment}

Concerning all groups of requirements audited in both industrial units, the "General requirements" group presented the highest scores (Table 2 and 6).

Unlike industry A, which lacked a closed video television or video surveillance system, industry B was equipped with internal and external surveillance cameras. However, these cameras were not directed to critical areas in the unit, such as the lobby, computer servers and final product packing room, nor identified in the unit's floor plan with their respective filming angles included. The existence of video surveillance cameras generates security and has a restraining effect on intentional food adulteration acts (Farias de Abreu et al., 2020; United States Department of Agriculture Food Safety and Inspection Service, 2008; Du et al., 2019). In addition, floor plan identification of cameras' location and operating angle supports a better control of video surveillance installation and positioning. 
Table 6. Audit scores of the "General requirements" group in both industries.

\begin{tabular}{|c|c|c|c|c|c|c|c|c|c|c|}
\hline \multirow[b]{2}{*}{ Industry } & \multicolumn{10}{|c|}{ Audit scores (proportion of compliance) } \\
\hline & $\begin{array}{c}\text { General } \\
\text { requirements } \\
\text { group } \\
\text { (max. 35) }\end{array}$ & $\begin{array}{c}\text { Video } \\
\text { surveillance } \\
\text { and security } \\
\text { software } \\
\text { (max. 11) }\end{array}$ & $\begin{array}{l}\text { Maintenance } \\
\text { (max. 6) }\end{array}$ & $\begin{array}{c}\text { Water } \\
\text { distribution } \\
\text { and storage } \\
\text { (max. 2) }\end{array}$ & $\begin{array}{c}\text { Mail } \\
(\max .2)\end{array}$ & $\begin{array}{c}\text { Analytical } \\
\text { control } \\
(\max .3)\end{array}$ & $\begin{array}{l}\text { Pest control } \\
\text { (max. 2) }\end{array}$ & $\begin{array}{l}\text { Traceability } \\
\text { (max. 3) }\end{array}$ & $\begin{array}{c}\text { Supplier } \\
\text { control } \\
(\max .4)\end{array}$ & $\begin{array}{c}\text { Emergency } \\
\text { contacts } \\
(\max .2)\end{array}$ \\
\hline A & $21 / 35(60 \%)$ & $1 / 11$ & $3 / 6$ & $2 / 2$ & $1 / 2$ & $3 / 3$ & $2 / 2$ & $3 / 3$ & $4 / 4$ & $2 / 2$ \\
\hline B & $27 / 35(77 \%)$ & $7 / 11$ & $3 / 6$ & $2 / 2$ & $1 / 2$ & $3 / 3$ & $2 / 2$ & $3 / 3$ & $4 / 4$ & $2 / 2$ \\
\hline
\end{tabular}

Both industries had a preventive maintenance plan for premises and equipments; however, no inventory of tools and utensils used in maintenance interventions existed, and those interventions were not recorded. Keeping records of maintenance operations is important because it identifies the employee who performed those interventions. The inventory also allows that employee to confirm that no object was forgotten at the maintenance site or equipment, preventing the obvious risk of physical contamination of the food produced (Henriques \& Fraqueza, 2015).

Regarding the procedures implemented in both units to manage incoming mail, in each industry there was an employee in charge of reception and dispatch of correspondence. Still, in both cases this employee had no training to act properly in case of any suspicious mail. According to food defense requirements, when suspicious mail is received, the designated employee must initiate a series of actions aiming to prevent and mitigate potential damage, such as handling letters or parcels with care and alerting the industrial unit security officer, as well as competent authorities (Fennelly \& Perry, 2018).

There were no vulnerabilities in the assessed requirements considering "water supply", "analytical control", "pest control", "traceability", "supplier control" and "emergency contacts" subsections. These requirements are frequently assessed as part of food safety management systems audits and have, therefore, been extensively planned and developed (Codex Alimentarius Commission, 2016).

\subsection{Main food defense vulnerabilities in other certified food industries}

In order to compare the food defense audit results of industries $\mathrm{A}$ and $\mathrm{B}$, audit reports on other previously certified food industries (according to at least one standard including food defense requirements: BRC, IFS and/or FSSC 22000) were assessed. Thus, a total of 45 food industries were considered, of which 38 were certified by the IFS standard, 6 by the FSSC 22000 and 1 by the BRC standard. All industries assessed had mature food safety management systems.

Considering the IFS standard, Table 7 displays the proportion of compliance of the food industries certified by that standard.

Considering those industries certified by the IFS standard, results revealed that the most common vulnerability was related to the requisite that establishes the need to have a documented food defense hazard analysis and associated risk assessment, annually reviewed and updated. Based on this hazard analysis and risk assessment, food business operators must identify areas critical for security in their premises and define an alert system, periodically tested for effectiveness. Another requirement also frequently indicated as vulnerable was the protection of critical areas, to which unauthorized access by employees, visitors and/or contractors must be prevented, and the control of those access points. Another frequent vulnerability was employees' training in food defense and related record keeping. 
Table 7. Compliance proportion of food defense requirements in industries $(n=38)$ certified by the IFS standard (International Featured Standards, 2014).

\begin{tabular}{|c|c|}
\hline Requirement description & $\begin{array}{l}\text { Proportion of compliance } \\
\text { (number of industries) }\end{array}$ \\
\hline $\begin{array}{l}\text { Food defense responsibilities are clearly defined. Those responsible should be key staff/ } \\
\text { have access to top management team. Sufficient knowledge in this area should be } \\
\text { demonstrated. }\end{array}$ & $27 / 38(71 \%)$ \\
\hline $\begin{array}{l}\text { A food defense hazard analysis and associated risks assessment must be performed and } \\
\text { documented. Based on this assessment and on legal requirements, critical security areas } \\
\text { must be identified. Food defense hazard analysis and risk assessment should be } \\
\text { conducted annually, or upon changes affecting food integrity. An appropriate alert } \\
\text { system must be defined and periodically checked for effectiveness. }\end{array}$ & $0 / 38(0 \%)$ \\
\hline $\begin{array}{l}\text { If legislation makes registration or on-site inspections necessary, evidence of these must } \\
\text { be provided. }\end{array}$ & $38 / 38(100 \%)$ \\
\hline $\begin{array}{l}\text { Based on a hazards analysis and assessment of associated risks, critical security areas } \\
\text { should be adequately protected to prevent unauthorized access. Access points should be } \\
\text { controlled. }\end{array}$ & $24 / 38(63 \%)$ \\
\hline $\begin{array}{l}\text { Procedures must be in place to prevent tampering and/or allow identification of } \\
\text { tampering. }\end{array}$ & $28 / 38(74 \%)$ \\
\hline $\begin{array}{l}\text { Visitor policy must include aspects of food defense plan. Delivery and loading staff in } \\
\text { contact with the product must be identified and must comply with company's access } \\
\text { rules. Visitors and external services providers must be identified in product storage areas } \\
\text { and should be registered upon access. They should be informed about site policies and } \\
\text { their access controlled accordingly. }\end{array}$ & $35 / 38(92 \%)$ \\
\hline $\begin{array}{l}\text { All employees must be trained in food defense on an annual basis or when significant } \\
\text { program changes occur. Training sessions must be documented. Employee hiring and } \\
\text { termination practices should consider security aspects as permitted by law. }\end{array}$ & $20 / 38(53 \%)$ \\
\hline $\begin{array}{l}\text { A documented procedure should exist for managing external inspections and regulatory } \\
\text { visits. Relevant personnel must be trained to execute the procedure. }\end{array}$ & $36 / 38(95 \%)$ \\
\hline
\end{tabular}

Considering the FSSC 22000 standard, Table 8 displays the proportion of compliance of the food industries certified by that standard.

Table 8. Compliance proportion of food defense requirements in certified industries $(n=6)$ by the FSSC 22000 standard (Foundation Food Safety System Certification 22000, 2019).

\begin{tabular}{cc}
\hline Requirement description & $\begin{array}{c}\text { Proportion of compliance } \\
\text { (number of industries) }\end{array}$ \\
\hline $\begin{array}{c}\text { Each organization shall assess the potential danger of acts of sabotage, vandalism, or } \\
\text { terrorism to their products and should establish protection measures. }\end{array}$ & $5 / 6(83 \%)$ \\
\hline $\begin{array}{c}\text { The organization shall identify, preferably in the facilities plan, the areas considered more } \\
\text { sensitive or susceptible to vandalism, sabotage and terrorism. Access to these places } \\
\text { should be denied to unauthorized personnel using locks or electronic keys. }\end{array}$ & $5 / 6(83 \%)$ \\
\hline
\end{tabular}

Regarding the FSSC 22000 standard, the most commonly nonconforming item was the one requiring food operators to assess hazards in products resulting from potential acts of sabotage, vandalism or terrorism, and establishing adequate protective measures. Identification of sensitive areas (including the floor plan) and the use of keys or electronic cards to control access to those areas were also mentioned as nonconforming in these industries. 
Vulnerabilities associated with food defense requirements in the only industry certified by the BRC standard in the assessed database are related to the inexistence of a documented food defense plan, which does not conform to BRC's standard requirements: "The company shall conduct a documented assessment of the security arrangements and potential risks to the products from any deliberate attempt to inflict contamination or damage". Sensitive or restricted areas must also be clearly identified, monitored and controlled, and security measures must be reviewed at least annually (British Retail Consortium, 2015).

\subsection{Comparison and analysis of the main vulnerabilities detected in the companies audited with those of other previously certified industries}

In general, both audited industries (A and B) and other previously certified enterprises assessed in this work had mature food safety management systems. Still, when comparing food defense requirements, the most common nonconforming requirements were related to: the inexistence of a food defense plan; no identification of critical areas within the unit; lack of access control; inexistence of effective and tested warning systems; and lack of adequate food defense training. These nonconformities were also detected in audits of industries A and B. Other authors reported similar results in previous works which assessed food defense practices in food establishments (Farias de Abreu et al., 2020; Kanagawa et al., 2014). Industry A, in particular, stated that it was not aware of the need to have a food defense plan. Food defense systems were initially developed for the food industry in the United States of America, following a series of malicious and intentional acts, especially after the incidents of September 11, 2001 (Davidson et al., 2017). These systems constitute, therefore, a defense against terrorist acts that are, up to this date and to the best of the authors' knowledge, a non-existing reality in the Portuguese food industry.

Several reasons might explain these results. In Portugal, the food industry is still embedded in a familiar spirit. In many cases, relatives make up a significant share of the staff. Family business operators relate to informal relations, altruistic leadership, poorly trained management and relatively unqualified personnel (Visser \& van Scheers, 2018). Therefore, these systems are regarded with surprise and understood as unnecessary by the food units' management. Furthermore, given the relatively low probability of an intentional adulteration incident, some food business operators may feel that the cost of developing a food defense strategy is disproportionate to the actual risk (Davidson et al., 2017). However, in the industries audited, some of the vulnerabilities would be easily mitigated without requiring a large investment of financial and human resources.

Due to the fact that food defense requirements were introduced more recently in the food industry, these requisites are usually integrated into an existing food safety management system. But while food safety addresses hazards, food defense focuses on threats (Bogadi et al., 2016; Soon et al., 2019). The similarity in nomenclature and resemblance of some recommended steps to develop food defense plans with the Hazard Analysis and Critical Control Points (HACCP) system seem to compromise understanding of the food defense concept. The relatively low score given to food defense requirements when considering all the requisites of food safety standards audits might also partly explain the results obtained.

Taken together, the results of this study revealed that although certification by standards that include food defense requirements is a necessity for food industries, several reasons contribute for their underestimation, leading to several food defense vulnerabilities in certified industries.

\section{Conclusion}

A food defense requirements audit of two meat-based food producing industries found that both units where above $50 \%$ of compliance, but several vulnerabilities were detected. Besides not having a food defense plan, both industries presented low compliance with "Personnel security" requirements, with no training in 
food defense. Other failures were related to identification of critical areas, access control and ineffective alert systems.

Similar vulnerabilities were identified when comparing these results with those of other food industries certified by the IFS, BRC and FSSC 22000 standards, leading to the conclusion that food defense is a relatively unexplored concept. Several reasons seem to explain these observations, namely the novelty of food defense requirements as part of food safety management systems and the familiar character of food businesses. As an initial intervention strategy, food defense training, to get both the staff and managers acquainted with the concept, would be of upmost importance for these industries.

\section{Acknowledgements}

The authors are grateful to the participating industries and the private certification association.

\section{References}

Blanchfield, J. R. (2013). Good manufacturing practice (GMP) in the food industry. In H. L. M. Lelieveld, M. A. Mostert \& J. Holah (Eds.), Hygiene in food processing: principles and practice (pp. 324-347). Cambridge, United Kingdom: Woodhead Publishing Ltd.

Bogadi, N. P., Banovic, M., \& Babic, I. (2016). Food defence system in food industry: perspective of the EU countries. Journal of Consumer Protection and Food Safety, 11(3), 217-226. http://dx.doi.org/10.1007/s00003-016-1022-8.

Brasil. (2014). Lei Geral do Trabalho em Funções Públicas (Lei nº. 35/2014 de 20 de Junho de 2014). Diário Oficial [da] República Federativa do Brasil, Brasília. Retrieved in 2020, June 8, from https://dre.pt/web/guest/legislacao-consolidada//lc/117652694/201901140000/indice

British Retail Consortium - BRC. (2015). Global standard food safety (No. 7). London, United Kingdom: The British Retail Consortium.

British Standards Institution. (2017). PAS 96:2017: guide to protecting and defending food and drink from deliberate attack. Retrieved in 2020, June 8, from https://www.food.gov.uk/sites/default/files/media/document/pas962017_0.pdf

Codex Alimentarius Commission. (2016). Guidelines on the application of general principles of food hygiene to the control of foodborne parasites (CAC/GL88-2016). Geneva, Switzerland: Codex Alimentarius Commission.

Davidson, R. K., Antunes, W., Madslien, E. H., Belenguer, J., Gerevini, M., Torroba Perez, T., \& Prugger, R.. (2017). From food defence to food supply chain integrity. British Food Journal, 119(1), 52-66. http://dx.doi.org/10.1108/BFJ-04-2016-0138.

Du, L., Zhang, W., Fu, H., Ren, W., \& Zhang, X. (2019). An efficient privacy protection scheme for data security in video surveillance. Journal of Visual Communication and Image Representation, 59, 347-362. http://dx.doi.org/10.1016/j.jvcir.2019.01.027.

European Union. (2003). Commission Recommendation 2003/361/EC of 6 May 2003 concerning the definition of micro, small and medium-sized enterprises. Official Journal of the European Union, European Union, L124/36.

Farias de Abreu, V. L., Silva, R., Luchese, R., Monteiro, S. S., Esmerino, E. A., \& Mathias, S. P. (2020). Impact assessment of the implementation of food defense plan in a Brazilian army military organization. Food Control, 118, 107288. http://dx.doi.org/10.1016/j.foodcont.2020.107288.

Fennelly, L. J., \& Perry, M. A. (Eds.), (2018). Physical security: 150 things you should know. United Kingdom: ButterworthHeinemann.

Food and Drug Administration - FDA. (2018). Carver + shock primer. Retrieved in 2020, December 9, from d/food-defenseprograms/carver-shock-primer

Food and Drug Administration - FDA. (2020). Food defense plan builder. Retrieved in 2020, December 9, from https://www.fda.gov/food/food-defense-tools-educational-materials/food-defense-plan-builder

Foundation Food Safety System Certification 22000 - FSSC 22000. (2019). FSSC 22000 scheme version 5. The Nederlands: Foundation FSSC 22000

Fredrickson, N. R. (2014). Food security: food defense and biosecurity. In N. K. Van Alfer (Ed.), Encyclopedia of agriculture and food systems (pp. 311-323). United States of America: Academic Press. http://dx.doi.org/10.1016/B978-0-444-52512-3.00036$\mathrm{X}$.

Global Food Safety Initiative Foundation - GFSI. (2020). Case study booklet. Retrieved in 2020, July 1, from https://mygfsi.com/wp-content/uploads/2020/02/GFSI-Case-Study-Booklet-2020-WEB-.pdf

Henriques, A. R., \& Fraqueza, M. J. (2015). Listeria monocytogenes and ready-to-eat meat-based food products: incidence and control. In T. Viccario (Ed.), Listeria monocytogenes: incidence, growth behavior and control (pp. 71-103). New York, United States of America: Nova Science Publishers Inc. 
Henriques, A. R., Gama, L. T., \& Fraqueza, M. J. (2017). Tracking Listeria monocytogenes contamination and virulenceassociated characteristics in the ready-to-eat meat-based food products industry according to the hygiene level. International Journal of Food Microbiology, 242, 101-106. PMid:27919005. http://dx.doi.org/10.1016/j.ijfoodmicro.2016.11.020.

Holah, J. T. (2013). Improving zoning within food processing plants. In H. L. M. Lelieveld, M. A. Mostert, J. Holah (Eds.), Hygiene in food processing: principles and practice (pp: 259-304). Cambridge, United Kingdom: Woodhead Publishing Ltd.

Holah, J. T., \& Taylor, J. (Eds.), (2003). Personal hygiene. In H. L. M. Lelieveld, M. A. Mostert, J. Holah (Eds.), Hygiene in food processing: principles and practice (pp. 288-309). Cambridge, United Kingdom: Woodhead Publishing Ltd.

International Featured Standards - IFS. (2014). Standard for auditing quality and food safety of food products, Version 6. Berlin, Germany: IFS Management GmbH.

International Organization for Standardization (ISO) /TS 22002-1:2009. (2009). Prerequisite programmes on food safety — Part 1: Food manufacturing. Geneva, Switzerland: International Organization for Standardization.

Kanagawa, Y., Akahane, M., Hasegawa, A., Yamaguchi, K., Onitake, K., Takaya, S., Yamamoto, S., \& Imamura, T. (2014). Developing a national food defense guideline based on a vulnerability assessment of intentional food contamination in Japanese food factories using the CARVER+Shock vulnerability assessment tool. Foodborne Pathogens and Disease, 11(12), 953-959. PMid:25496071. http://dx.doi.org/10.1089/fpd.2014.1767.

Manning, L. (2019). Food defence: refining the taxonomy of food defence threats. Trends in Food Science \& Technology, 85, 107-115. http://dx.doi.org/10.1016/j.tifs.2019.01.008.

Manning, L., \& Soon, J. M. (2016). Food Safety, Food Fraud, and Food defense: A Fast Evolving Literature. Journal of Food Science, 81(4), 823-834. PMid:26934423. http://dx.doi.org/10.1111/1750-3841.13256.

PORDATA. (2020). Base de dados Portugal contemporâneo - Empresas no sector da indústria transformadora: total e por tipo. Retrieved in 2020, December 21, from https://www.pordata.pt

Soon, J. M., Krzyzaniak, S. C., Shuttlewood, Z., Smith, M., \& Jack, L. (2019). Food fraud vulnerability assessment tools used in food industry. Food Control, 101, 225-232. http://dx.doi.org/10.1016/j.foodcont.2019.03.002.

Sprenger, R. A. (2017). Training and education of food handlers. In R. A. Sprenger. Hygiene for management a text for food hygiene courses (pp: 63-70). Doncaster, United Kingdom: Highfield Publications.

United States Department of Agriculture Food Safety and Inspection Service - USDA. (2008). Developing a food defense plan for meat and poultry slaughter and processing plants. Retrieved in 2020 , June 10 , from https://www.fsis.usda.gov/shared/PDF/Food_Defense_Plan.pdf

Visser, T., \& van Scheers, L. (2018). Can family business managers manage family business risks? Journal of Contemporary Management Issues, 23(1), 123-137. http://dx.doi.org/10.30924/mjcmi/2018.23.1.123.

Wallace, C. A., Holyoak, L., Powell, S. C., \& Dykes, F. C. (2014). HACCP: the difficulty with hazard analysis. Food Control, 35(1), 233-240. http://dx.doi.org/10.1016/j.foodcont.2013.07.012.

Funding: None. 
Appendix A. Checklist sections, evaluated items and total scores.

\begin{tabular}{|c|c|c|}
\hline Sections & $\underline{\text { Sub-sections and questions }}$ & Score \\
\hline External security & $\begin{array}{l}\text { External Perimeter: Is the facility's external perimeter secured with a fence/wall? Is a } \\
\text { routine inspection to the perimeter performed periodically to check for damage and } \\
\text { necessary repairs? Is the facility perimeter well-lit during dark hours? Building and } \\
\text { structure: Are the facility's buildings constructed of materials able to resist intruders' } \\
\text { unlawful entry? Are the ceilings, walls, doors, windows and pavement appropriately } \\
\text { proofed? Can doors and windows be opened exclusively from the inside? Do doors and } \\
\text { windows have trigger alarms if opened from the outside? Do emergency doors sound } \\
\text { alarms if opened from the outside? Are there periodical meetings with security personnel } \\
\text { to assess security alarms/alerts and improve security? Access control: Are vehicles } \\
\text { controlled and supervised inside the facilities? Are employees' vehicles easily identified? } \\
\text { In the case of access to the inside perimeter, are there restrictions to visitor's vehicles } \\
\text { parking (near cargo handling and storage areas)? Are all the premise's entries and exits } \\
\text { clearly identified? Are all visitor/contractor entries recorded (listing name, reason for } \\
\text { visit, time of arrival and departure)? Are these records kept for at least } 30 \text { days? Are all } \\
\text { visitors/contractors adequately identified while inside the facilities? Are all } \\
\text { visitors/contractors escorted while inside the facilities? Are only authorized persons } \\
\text { allowed in critical areas? Is there access control regarding employees and } \\
\text { visitors/contractors in processing, packaging and final product areas? Shipping and } \\
\text { dispatching: Are drivers identified in all deliveries and records kept? Are all deliveries } \\
\text { (raw materials, packaging, subsidiary materials) notified? Are delivered materials } \\
\text { inspected prior to use? In case of non-conforming deliveries, are suppliers notified? Is } \\
\text { there a written procedure on how to handle unexpected deliveries of raw } \\
\text { materials/packaging/subsidiary materials? Is there a designated employee in charge of } \\
\text { supervising all deliveries/shippings? Are these activities recorded? Are records kept for } \\
\text { at least } 30 \text { days? }\end{array}$ & 27 \\
\hline
\end{tabular}

Raw materials storage: Are there specific areas for raw materials storage? Are those areas identified? Is the access to those areas restricted? Is there a record for access control to these critical areas? Are there regular audits of these critical areas? Are there written evidences of those audits? Subsidiary materials/chemical storage: Are there specific storage areas for these materials? Are those areas identified? Is the access to those areas restricted? Is there a record for access control to these critical areas? Are there regular audits to these critical areas? Are there written evidences of those audits? Final products storage: Are there specific areas for final products storage? Are those areas identified? Is access to those areas restricted? Is there a record for access control to these critical areas? Are there regular audits to these critical areas? Are there written evidences of those Internal security audits? Returned/withdrawn/suspicious products: Are there specific storage areas for these materials? Are those areas identified? Is access to those areas restricted? Are records kept about the destination given to those products? Is there a written procedure for handling of suspicious raw materials/ final products? Access control: Is there any kind of alarm inside the facilities? Is there any kind of access control to critical areas (keys/card/biometric system)? Are employees aware of the need to report lost keys/access cards to security personnel? Is there a list of authorized staff for critical areas? Do security personnel have access to this list? Are critical areas properly identified? Is there emergency lighting inside the facilities? Is there access to ventilation/air conditioning, water storage and electric power controlled? When a potential threat is detected, is it immediately investigated and recorded by security personnel? 


\begin{tabular}{|c|c|c|}
\hline Sections & $\underline{\text { Sub-sections and questions }}$ & Score \\
\hline $\begin{array}{c}\text { Personnel } \\
\text { security }\end{array}$ & $\begin{array}{l}\text { Employee's hiring: Is there a written procedure to conduct a background (criminal } \\
\text { record) check before hiring a new employee/ temporary worker? Are employees, } \\
\text { visitors/contractors given a written document with critical areas identification and access } \\
\text { restriction? Are all employees and temporary workers properly identified within the } \\
\text { facilities? Training: Are employees trained before starting their functions? Are } \\
\text { employees trained in food defense? Does training focuses on security threats? Does } \\
\text { training include the need to immediately report the loss of keys/cards? Does training } \\
\text { focuses on tampering detection in raw materials/final products? Personnel behavior: Is } \\
\text { staff wearing appropriate uniforms? Is it possible to differentiate employees from } \\
\text { different departments by their uniform? Is the uniform washed in the facilities' laundry? } \\
\text { Is there any kind of incentive for employees who report suspicious activity and security } \\
\text { violations? Are personnel lockers inspected regularly? Are inspection records kept? } \\
\text { Employment contract revision: Is there a periodical check on employee's criminal } \\
\text { records, especially of those working in critical areas? In case of employee's dismissal, is } \\
\text { this communicated to other staff members, including security personnel? }\end{array}$ & 16 \\
\hline
\end{tabular}

Video surveillance and security software: Are there any external video cameras? Are there any internal video cameras? Are these cameras directed to critical areas (such as the lobby, computer servers and final product packaging room)? Are these cameras identified in the unit's floor plan? Is the filming angle included in the floor plan? Are production lines monitored by video surveillance? Is the video surveillance system computer managed? Is there a restricted access to that/those computer(s)? Is there a hacker/virus detection software? Is there a responsible person for identification and passwords attribution? Are passwords regularly updated? Maintenance: Are premises and equipment well maintained? Is there a preventive maintenance plan? Are all maintenance interventions recorded? Is maintenance verification performed and recorded? Is there an inventory of maintenance tools and utensils? Is there a periodical inventory of tools and utensils posing a potential risk (knifes, blades, etc.) in each

General requirements section? Water distribution and storage: Are water distribution and storage facilities regularly inspected? Are records kept? Mail: Is there an employee in charge of managing mail? Has this employee been trained on how to act in case of a suspicious mail event? Analytical control: Is there routine microbiological control of raw materials? Is there routine microbiological control of final products? Is there routine microbiological control of water? Pest control: Are control devices properly protected from unlawful use? Are control devices adequate for food producing premises? Traceability: Are there records of upstream traceability? Are there records of downstream traceability? Is there a regular traceability test evidenced by records? Supplier control: Is there any suppliers' selection and control system? Do suppliers have a food defense system? Are suppliers' contracts updated and reviewed? Are suppliers' contacts readily available and updated? Emergency contacts: Is there an emergency contacts list (medical emergency, police, firefighters)? Are clients' contacts readily available and updated? 